2

I N S N

\title{
KEPUASAN PERKAWINAN DENGAN KESEJAHTERAAN SUBJEKTIF PEREMPUAN DENGAN PROFESI GURU SEKOLAH DASAR
}

\author{
AJENG SISTA ANINDYA ${ }^{1 *} \&$ CHRISTIANA HARI SOETJININGSIH ${ }^{1}$ \\ ${ }^{1}$ Fakultas Psikologi, Universitas Kristen Satya Wacana Salatiga
}

\begin{abstract}
ABSTRAK
Penelitian ini bertujuan untuk mengetahui apakah ada hubungan positif yang signifikan antara kepuasan perkawinan dengan kesejahteraan subjektif pada guru SD perempuan di Kelurahan Kratonan Kecamatan Serengan, Kota Surakarta. Metode pengumpulan data yang digunakan dalam penelitian ini adalah skala psikologi. Skala yang digunakan dalam penelitian ini yaitu skala yang diadaptasi oleh penulis berdasarkan Marriage Satisfacton Scale $(\alpha=.941)$ dan skala kedua yaitu skala kesejahteraan subjektif yang diadaptasi oleh penulis berdasarkan Positive and Negative Affect Schedule (PANAS-SF) dan Satisfaction With Life Scale (SWLS) $(\alpha=.941)$. Partisipan dalam penelitian ini adalah 59 guru SD perempuan di Kelurahan Kratonan Kecamatan Serengan Kota Surakarta dan menggunakan teknik Purposive Sampling. Pengujian hipotesis dan korelasi antara kepuasan perkawinan dengan kesejahteraan subjektif guru SD perempuan di Kelurahan Kratonan Kecamatan Serengan Kota Surakarta menggunakan uji korelasi Pearson's Product Moment Correlation. Hasil penelitian ini menunjukan adanya hubungan positif yang signifikan antara kepuasan perkawinan dan kesejahteraan subjektif guru SD perempuan di Kelurahan Kratonan Kecamatan Serengan Kota Surakarta (r=.970; $\mathrm{p}<.05)$.
\end{abstract}

Kata kunci: kepuasan perkawinan, kesejahteraan subjektif, perempuan, guru SD

\begin{abstract}
This study aims to determine whether there was a significance positive correlation between marital satisfaction and subjective well being of elementary school female teachers in Kelurahan Kratonan Kecamatan Serengan Surakarta City. Psychology scale was used as data collection method of this study. This scale was adapted by the author based on marriage satisfaction scale created by Olson and Fowers (1993) $(\alpha=.941)$ and the next scale was adapted by the author based on Positive and Negative Affect Schedule (PANAS-SF) and Satisfaction with Life Scale (SWLS) created by Diener (2000) ( $\alpha=.941)$. About 59 elementary school female teachers in Kelurahan Kratonan Kecamatan Serengan Surakarta City have participated in this research and been measured by a purposive sampling technique. Pearson Correlation Product Moment was used to find out about the hypothesis and correlation testing between marital satisfaction and subjective well being of elementary school female teachers in Kelurahan Kratonan Kecamatan Serengan Surakarta City. The results show that there is a positive correlation between marital satisfaction and subjective well being of elementary school female teachers in Kelurahan Kratonan Kecamatan Serengan Surakarta City ( $r=.970, p<.05)$.
\end{abstract}

Keywords: marital satisfaction, subjective well being, female, primary school teacher 
INSAN Jurnal Psikologi dan Kesehatan Mental, 2017, Vol. 2(1), 42-50, doi: 10.20473/jpkm.v2i12017.44-50 Dikirimkan: 22 Mei 2017 Diterima: 31 Mei 2017 Diterbitkan: 26 Juni 2017

Editor: Ilham Nuralfian

*Alamat korespondensi: Jalan Diponegoro 52-60 Salatiga, Jawa Tengah 50714. Surel: anindyastara@gmail.com

Naskah ini merupakan naskah dengan akses terbuka dibawah ketentuan the Creative Common Attribution License (http://creativecommons.org/licenses/by/4.0), sehingga penggunaan, distribusi, reproduksi dalam media apapun atas artikel ini tidak dibatasi, selama sumber aslinya disitir dengan baik.

\section{PEND A H U L U A N}

Setiap individu tentunya akan mengalami beragam peristiwa baik yang menyenangkan maupun tidak menyenangkan selama perjalanan hidupnya. Cara mereka menyikapi setiap peristiwa yang dialami juga berbeda-beda. Ada individu yang mampu mengatasi peristiwa yang tidak menyenangkan tetapi ada juga yang tidak mampu mengatasinya. Apabila individu mampu mengatasi masalah yang sedang dihadapinya, maka akan menimbulkan perasaan bahagia. Sebaliknya, apabila individu tidak mampu mengatasi masalah yang sedang dihadapinya maka akan timbul emosi yang tidak menyenangkan dalam hidupnya, bahkan keadaan ini dapat menyebabkan individu yang bersangkutan merasa tidak puas atau tidak bahagia dalam menjalani kehidupannya. Untuk itulah, pemaknaan hidup yang positif merupakan hal yang sangat penting, agar manusia yang dengan berbagai latar belakang dan juga dengan berbagai subjektivitas yang dimiliki, bisa meraih kebahagiaan atau disebut dengan istilah kesejahteraan subjektif (Arbiyah, 2008).

Carr (2004) memberikan definisi yang sama antara kebahagiaan dan kesejahteraan subjektif yaitu sebuah keadaan psikologi positif yang meliputi tingginya tingkat kepuasan hidup dan emosi positif. Penelitian lain yang dilakukan oleh Diener (dalam Ryan \& Deci, 2001) memberikan definisi bahwa kesejahteraan subjektif adalah istilah untuk menjelaskan hal apa yang membuat kehidupan seseorang lebih baik sebagai evaluasi individu terhadap kehidupan mengenai bagaimana dan mengapa individu mengalami kehidupan dalam cara yang positif, sehingga pengalaman pribadi mereka berkaitan dengan kualitas hidup yang dirasakan.

Menurut Diener dan Oishi (2005) terdapat dua komponen dasar kesejahteraan subjektif yaitu kepuasan hidup (life satisfaction) sebagai komponen kognitif dan kebahagiaan (happiness) sebagai komponen afektif. Kepuasan hidup termasuk dalam komponen kognitif karena keduanya didasarkan pada keyakinan tentang kehidupan seseorang. Evaluasi kognitif dilakukan saat seseorang memberikan evaluasi secara sadar dan menilai kepuasan mereka terhadap kehidupan secara keseluruhan atau penilaian evaluatif mengenai aspek-aspek khusus dalam kehidupan, seperti kepuasan kerja, minat, dan hubungan (Diener \& Oishi, 2005). Kepuasan hidup merupakan penilaian individu terhadap kualitas kehidupannya secara menyeluruh. Seorang individu yang dapat menerima diri dan lingkungan secara positif akan merasa puas dengan hidupnya (Hurlock, 1999).

Komponen yang kedua yaitu komponen afektif (kebahagiaan) didefinisikan sebagai reaksi individu terhadap kejadian-kejadian dalam hidup yang meliputi emosi (afek) yang menyenangkan dan emosi (afek) yang tidak menyenangkan. Afek positif atau emosi yang menyenangkan merupakan bagian dari kesejahteraan subjektif yang dialami individu sebagai reaksi yang muncul pada diri individu karena hidupnya berjalan sesuai dengan apa yang diinginkan (Diener \& Oishi, 2005). Menurut Seligman (2005), emosi positif dapat dibedakan menjadi tiga kelompok, yaitu emosi positif akan masa lalu, masa sekarang dan masa depan. Emosi positif masa depan meliputi optimisme, harapan, keyakinan dan

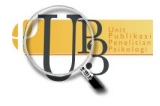


kepercayaan. Emosi positif masa sekarang mencakup kebahagiaan, ketenangan, semangat. Emosi positif tentang masa lalu adalah kepuasan, kelegaan, kesuksesan, kebanggaan dan kedamaian. Berbeda dengan afek positif, maka afek negatif merupakan suasana hati dan emosi yang tidak menyenangkan yang muncul sebagai reaksi negatif dari kejadian yang dialami oleh individu dalam hidup mereka, kesehatan serta lingkungan mereka (Diener \& Oishi, 2005). Emosi negatif yang paling umum dirasakan adalah kesedihan, kemarahan, kecemasan, kekhawatiran, stres, frustrasi, rasa malu dan bersalah serta iri hati.

Tercapainya kehidupan yang (sejahtera) tentunya dambaan bagi semua individu tak terkecuali bagi wanita karir yang berstatus menikah. Menurut Santrock (2002) pada saat seorang wanita sudah menikah, mereka dihadapkan pada pertanyaan apakah harus memilih salah satu diantara karir dan keluarga, atau mengembangkan antara keduanya. Tidak cukup sampai disitu, seiring dengan perkembangan jaman dan tuntutan peran, maka semakin banyak juga persoalan yang dialami oleh para wanita (ibu rumah tangga) yang bekerja diluar rumah, seperti mengatur waktu dengan suami dan anak hingga mengurus tugas-tugas rumah tangga dengan baik.

Ketika perempuan memutuskan untuk menjadi wanita karir, mereka semua pasti mengalami perasaan bahagia dan tidak bahagia dalam pekerjaan mereka. Perasaan bahagia misalnya dapat terjadi ketika seorang wanita karir dinilai lebih mampu mandiri dan memiliki lingkup sosial lebih luas, sehingga dengan hal tersebut seorang wanita karir memiliki rasa percaya diri dan harga diri yang lebih baik (Abbort, 1992). Berlawanan dengan hal tersebut, maka perasaan tidak bahagia dapat terjadi ketika seorang wanita karir merasa tertekan, kurang mendapat dukungan dari suami, mengalami konflik dengan pasangan, memiliki masalah dan tuntutan dalam pekerjaan, memiliki hubungan yang kurang harmonis antar anggota keluarga, merasakan kebutuhan finansial yang semakin tinggi dan tidak bisa mencapai aktualisasi diri (Apollo \& Andi, 2012).

Fenomena wanita bekerja sebenarnya bukanlah hal baru di tengah masyarakat kita. Memilih dan menjalankan peran sebagai wanita karir bukan lagi menjadi hal baru di kalangan masyarakat. Saat ini wanita tidak hanya berperan sebagai ibu rumah tangga saja, tetapi mempunyai peran lain di luar rumah yaitu sebagai wanita karir. Tujuan wanita memutuskan berkarir, menurut Suryani (2008) diantaranya adalah untuk membantu memenuhi kebutuhan finansial keluarga, mendapatkan kesempatan mengaktualisasikan diri, berkreasi, dan produktif untuk dirinya maupun orang lain.

Bekerja menjadi guru SD merupakan salah satu dari bermacam-macam pekerjaan yang menjadi pilihan dari seorang wanita karir. Secara umum permasalahan yang dialami oleh guru SD adalah memahami karakter siswa yang sangat beragam, mendidik siswa sehingga mereka memiliki kualitas yang baik dalam segi psikis, mental, maupun spiritual, menyelesaikan masalah atau konflik antar siswa, dan menemukan metode mengajar yang sesuai untuk anak SD supaya bisa mengerti pelajaran yang disampaikan.

Dewasa ini hampir semua Sekolah Dasar menerapkan Kurikulum 2013 dalam pelaksanaan Kegiatan Belajar Mengajar. Berdasarkan wawancara dengan beberapa guru SD perempuan di Kelurahan Kratonan pada tanggal 12 Oktober 2016, penulis dapat mengetahui bahwa dengan adanya perubahan Kurikulum Tingkat Satuan Pendidikan (KTSP) menjadi Kurikulum 2013, mereka membutuhkan penyesuaian diri dengan bahan dan waktu mengajar. Mereka dituntut untuk memberikan pengajaran yang lebih mengarah kepada diskusi dan eksperimen, dibutuhkan tingkat kesabaran yang tinggi dalam menghadapi masalah ini karena mereka merasa memiliki kewajiban untuk membuat suasana belajar yang kondusif dan menyenangkan bagi murid-murid. Selama ini mereka tetap merasa bahagia, meskipun ada saja masalah yang muncul dalam pekerjaan namun masalah-masalah tersebut dapat diatasi dengan baik. 
Penelitian yang dilakukan oleh Bradbury, Fincham, \& Beach (2000) menyatakan bahwa (kesejahteraan subjective wanita karir)dipengaruhi oleh tingginya tingkat kepuasan pernikahan. Pendapat tersebut didukung oleh Olson (2000) yang mengungkapkan bahwa kepuasan pernikahan berpengaruh positif terhadap (kesejahteraan subjektif)kebanyakan orang. Beberapa partisipan mengatakan bahwa walaupun mengalami permasalahan dalam hal pekerjaan, namun mereka selalu mendapatkan dukungan dari keluarga dan pasangan untuk terus bekerja dan melakukan yang terbaik. Dukungan dari keluarga dan pasangan ini yang membuat partisipan merasa puas dengan kehidupan perkawinan mereka. Berdasarkan pernyataan tersebut dapat diketahui bahwa faktor lain yang mempengaruhi (kesejahteraan subjektif) mereka yaitu kepuasan dalam menjalani kehidupan perkawinan.

Menurut Fowers dan Olson (1993) kepuasan perkawinan (marital satisfaction) adalah perasaan subyektif yang dirasakan pasangan suami istri berkaitan dengan aspek yang ada dalam suatu perkawinan, seperti rasa bahagia, puas, serta pengalaman-pengalaman yang menyenangkan bersama pasangannya (Fowers \& Olson, 1993). Kepuasan perkawinan merupakan tingkat keberhasilan suami istri dalam menyesuaikan diri dan menghadapi setiap permasalahan dalam rumah tangga (Hurlock, 1980). Menurut Fowers dan Olson (1993) seberapa tinggi tingkat kepuasan perkawinan seseorang dapat dilihat dari 10 komponen yaitu :

a) Kepribadian. Setiap individu yang sudah menikah pasti memiliki persepsi terhadap sikap atau kepribadian yang dimiliki oleh pasangannya.

b) Komunikasi. Individu yang memiliki sikap dan penilaian positif terhadap komunikasi dalam hubungannya dan merasa dimengerti oleh pasangannya dapat menyatakan perasaan dan keyakinan-keyakinannya secara terbuka.

c) Resolusi konflik. Ketika pasangan suami istri sedang menghadapi konflik, mereka memiliki strategi dan proses dalam menyelesaikan masalah atau konflik tersebut.

d) Pengaturan keuangan. Sikap dan kepedulian seseorang tentang cara pengaturan masalah keuangan dan kepuasannya dengan keadaan ekonomi mereka.

e) Aktivitas waktu luang. Pengaturan aktivitas di waktu luang dilakukan oleh pasangan suami istri supaya mereka mendapatkan waktu yang berkualitas.

f) Hubungan seksual. Komponen hubungan seksual ini meliputi sejauh mana pasangan puas dengan ekspresi kasih sayang satu sama lain, sikap terhadap perilaku seksual, kenyamanan dalam mendiskusikan isu-isu seksual, kepuasan mengenai kelahiran anak dan kesetiaan pasangan dalam hal seksual.

g) Anak dan Pengasuhan. Selama menjalani kehidupan perkawinan, pasangan suami istri memiliki penilaian pasangan tentang bagaimana peran dan tanggungjawab sebagai orang tua, kesepakatan tentang mendisiplinkan anak dan kesesuaian tujuan serta nilai-nilai yang diinginkan untuk anak.

h) Keluarga dan Teman. Setiap individu yang sudah menikah memiliki penilaian mengenai hubungannya dengan saudara, orang tua, teman, mertua, ipar serta teman dari pasangan.

i) Kesetaraan peran. Tugas utama dari pasangan suami istri adalah memahami dan menghargai mengenai mengenai fungsi dan keberadaannya dalam menjalankan tanggungjawab dalam rumah misalnya pembagian pekerjaan rumah, peran sebagai orang tua, dan peran mencari nafkah.

j) Agama. Dalam komponen ini, setiap individu memiliki sikap dan kepedulian dalam hal keyakinan dan praktek keagamaan dalam sebuah keluarga.

Dengan demikian salah satu faktor yang mempengaruhi kesejahteraan subjektif adalah kepuasan perkawinan karena kepuasan perkawinan mengandung penilaian subyektif terhadap beberapa hal mengenai persepsi dalam perkawinan seperti bahagia, puas, dan pengalaman yang menyenangkan

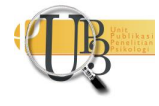


bersama pasangan. Hasil penelitian yang berkaitan dengan kesejahteraan subjektif ditinjau dari kepuasan perkawinan belum banyak ditemui. Dari uraian yang telah dipaparkan maka penulis tertarik melakukan penelitian dengan judul "Hubungan Antara Kepuasan Perkawinan dengan kesejahteraan subjektif pada Guru SD Perempuan di Kelurahan Kratonan Surakarta”.

\section{E T O D E}

\section{Partisipan}

Partisipan dalam penelitian ini adalah 59 guru SD perempuan, bekerja di SD Negeri Kemasan 1, SD Negeri Kemasan 2, dan SD Negeri Kratonan Kelurahan Kratonan Kecamatan Serengan Kota Surakarta, berumur 24-59 tahun, sudah menikah dan memiliki anak. Penelitian ini menggunakan teknik purposive sampling, artinya adalah penentuan sampel dengan pertimbangan tertentu (Sugiyono, 2001).

\section{Pengukuran}

Pengumpulan data dalam penelitian ini menggunakan dua skala, yaitu skala kesejahteraan subjektif dan skala kepuasan perkawinan. Skala merupakan suatu metode pengumpulan data yang berisi beberapa pertanyaan atau pernyataan (aitem) yang secara tidak langsung dapat mengungkap atribut yang hendak diukur (Azwar, 2012).

Skala Kepuasan Perkawinan. Skala ini diadaptasi oleh penulis berdasarkan Marriage Satisfacton Scale yang dibuat oleh Olson \& Fowers (1993). Skala kepuasan perkawinan tersebut menggunakan skala Likert yang terdiri dari 25 item dan menyediakan 4 pilihan jawaban, antara lain: SS (Sangat Sesuai), S (Sesuai), TS (Tidak Sesuai), STS (Sangat Tidak Sesuai). Berdasarkan perhitungan uji seleksi item dan reliabilitas skala kepuasan perkawinan sebanyak dua kali putaran, yang terdiri dari 25 item, diperoleh item yang gugur sebanyak 3 item sehingga menyisahkan 22 item yang valid dengan koefisien korelasi item totalnya bergerak antara -.025 - .891. Penelitian ini menghasilkan koefisien alpha pada skala kepuasan perkawinan sebesar .941. Hal ini menunjukkan bahwa skala kepuasan perkawinan reliabel karena suatu alat ukur di katakan reliabel apabila nilai $\alpha>.5$ (Azwar, 2001).

Skala Kesejahteraan subjektif. Skala kesejahteraan subjektif diadaptasi oleh penulis berdasarkan Positive and Negative Affect Schedule (PANAS-SF) yang dibuat oleh Watson (1988). Skala yang kedua diadaptasi oleh penulis berdasarkan Satisfaction With Life Scale (SWLS) yang dibuat oleh Diener (1985). Skala kesejahteraan subjektif tersebut menggunakan skala Likert yang terdiri dari 28 item dan menyediakan 4 pilihan jawaban, antara lain; SS (Sangat Sesuai), S (Sesuai), TS (Tidak Sesuai), STS (Sangat Tidak Sesuai). Berdasarkan perhitungan uji seleksi item dan reliabilitas skala kesejahteraan subjektif sebanyak dua kali putaran, yang terdiri dari 28 item, diperoleh item yang gugur sebanyak 4 item sehingga menyisahkan 24 item yang valid dengan koefisien korelasi item totalnya bergerak antara .21 - .766. Penelitian ini menghasilkan koefisien alpha pada skala kesejahteraan subjektif sebesar .929. Hal ini menunjukkan bahwa skala kesejahteraan subjektif reliabel karena suatu alat ukur di katakan reliabel apabila nilai $\alpha>.5$ (Azwar, 2001).

\section{Analisis Data}

Penghitungan penelitian ini menggunakan bantuan program statistik SPSS versi 20.00. Validitas item pada penelitian ini dihitung dengan menggunakan Pearson (Azwar, 2010). Pada penelitian ini, Cronbach Alpha digunakan untuk menguji reliabilitas. Pengujian normalitas pada penelitian ini

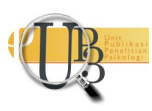


menggunakan Kolmogorov-Smirnov. Uji linearitas dalam penelitian ini dihitung dengan ANOVA table of linearity. Pengujian hipotesis dilakukan dengan menggunakan Pearson Correlation Product Moment.

\section{HAS IL PENELITIAN}

Berdasarkan uji asumsi yang telah dilakukan sebelumnya dapat diketahui bahwa data berdistribusi normal ( $p>.05)$ dan kedua variabel penelitian linier ( $p>.05)$, maka uji korelasi yang dilakukan menggunakan Pearson Correlation Product Moment. Berdasarkan hasil uji korelasi antar kedua variabel dapat disimpulkan bahwa terdapat hubungan positif yang signifikan $(r=.970 ; p<.05)$ antara kepuasan perkawinan dengan kesejahteraan subjektif, yang berarti makin tinggi kepuasan perkawinan makin tinggi kesejahteraan subjektif pada guru SD perempuan di Kelurahan Kratonan.

\section{I S K U S I}

Hasil uji korelasi mengenai hubungan antara kepuasan perkawinan dan kesejahteraan subjektif menunjukkan angka korelasi antara kesejahteraan subjektif dengan kepusan perkawinan adalah .970 $(\mathrm{p}<.05)$. Hal ini berarti ada hubungan positif yang signifikan antara kepuasan perkawinan dan kesejahteraan subjektif.

Menurut Arbiyah (2008), apabila individu mampu mengatasi masalah yang sedang dihadapinya, maka akan menimbulkan perasaan bahagia. Hasil penelitian terdahulu tersebut sesuai dengan pernyataan beberapa partisipan yang mengatakan bahwa dengan adanya perubahan Kurikulum Tingkat Satuan Pendidikan (KTSP) menjadi Kurikulum 2013, mereka membutuhkan penyesuaian diri dengan bahan dan waktu mengajar. Mereka dituntut untuk memberikan pengajaran yang lebih mengarah kepada diskusi dan eksperimen, dibutuhkan tingkat kesabaran yang tinggi dalam menghadapi masalah ini karena mereka merasa memiliki kewajiban untuk membuat suasana belajar yang kondusif dan menyenangkan bagi murid-murid. Selama ini mereka tetap merasa bahagia, meskipun ada saja masalah yang muncul dalam pekerjaan namun masalah-masalah tersebut dapat diatasi dengan baik.

Faktor yang lain yang mempengaruhi kebahagiaan guru SD perempuan di Kelurahan Kratonan yaitu merasa puas dalam menjalani kehidupan rumah tangga karena mendapatkan dukungan dari keluarga dan pasangan untuk terus bekerja dan melakukan yang terbaik. Hal ini tidak mendukung penelitian yang dilakukan oleh Apollo dan Cahyadi (2012) yang menyatakan bahwa ketidakbahagiaan wanita karir disebabkan oleh adanya rasa tertekan, kurangnya dukungan suami, konflik kehadiran anak, tingginya tuntutan dan masalah dalam pekerjaan, hubungan antar anggota keluarga yang kurang harmonis, tingginya kebutuhan finansial dan tidak tercapainya aktualisasi diri.

Dengan demikian salah satu faktor yang mempengaruhi kesejahteraan subjektif adalah kepuasan perkawinan. Karena kepuasan perkawinan mengandung penilaian subyektif terhadap beberapa hal mengenai persepsi dalam perkawinan seperti bahagia, puas, dan pengalaman yang menyenangkan bersama pasangan. Berdasarkan hasil penelitian tersebut dapat dikatakan bahwa semakin tinggi kepuasan perkawinan guru SD perempuan di Kelurahan maka semakin tinggi pula kesejahteraan subjektif yang mereka miliki. Hasil penelitian ini sesuai dengan penelitian Bradbury, Fincham, \& Beach (2000) yang menyatakan bahwa kebahagiaan wanita karir juga dipengaruhi oleh tingginya tingkat kepuasan pernikahan.

\section{S I M P U L A N}

Dari hasil uji korelasi, menunjukkan bahwa ada hubungan positif yang signifikan antara kepuasan perkawinan dan kesejahteraan subjektif pada guru SD perempuan di Kelurahan Kratonan Kecamatan Serengan Kota Surakarta. Pada wanita karir yang berstatus sudah menikah disarankan dapat INSAN Jurnal Psikologi dan Kesehatan Mental 2017, Vol. 2(1), 44-50

doi: $10.20473 /$ jpkm.v2i12017.44-50

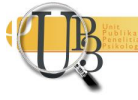


mempertahankan kepuasan pernikahannya dengan cara menjaga komunikasi dan meluangkan waktu bersama pasangan. Bagi peneliti selanjutnya diharapkan mampu mengembangkan variabel lain dalam mengetahui kebahagiaan seperti self esteem, religiusitas, hubungan sosial, potensi diri.

\section{PUSTAKA ACUAN}

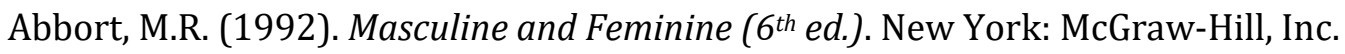

Apollo \& Cahyadi, A. (2012). Konflik Peran Ganda Perempuan Menikah Yang Bekerja Ditinjau Dari Dukungan Sosial Keluarga dan Penyesuaian Diri. Skripsi. (Tidak Diterbitkan). Madiun: Fakultas Psikologi. Universitas Katolik Widya Mandala

Arbiyah, N. Nurwianti, F. Oriza, I. (2008). Hubungan Bersyukur dan Subjective Well-Being Pada Penduduk Miskin, Jurnal Psikologi Sosial, 14(1).

Azwar, S. (2001). Penyusunan Skala Psikologi. Yogyakatra: Pustaka Pelajar

Azwar, S. (2010). Metode Penelitian. Yogyakarta: Pustaka Pelajar.

Bradbury, T. N., Fincham, F. D., \& Beach, S. R. (2000). Research on the nature and determinants of marital satisfaction: A decade in review. Journal of Marriage and Family, 62 (4), 964-980.

Carr, A. (2004). Positive Psychology: The Science of Happiness and Human Strengths. Philosophy of Education Journal, 38, 55-73.

Diener, E. D., Emmons, R. A., Larsen, R. J., \& Griffin, S. (1985). The satisfaction with life scale. Journal of Personality Assessment, 49(1), 71-75.

Diener, E., \& Oishi, S. (2005). The nonobvious social psychology of happiness. Psychological Inquiry, 16(4), 162-167.

Fowers, B. J., \& Olson, D. H. (1993). ENRICH Marital Satisfaction Scale: A brief research and clinical tool. Journal of Family psychology, 7(2), 176.

Hurlock, E.B. (1999). Psikologi Perkembangan Suatu Rentang Kehidupan. Jakarta : Erlangga.

Olson, D. F., DeFrain J, \& Skogrand L. (2011). Marriages Families: Intimacy, Diversity, and Strengths. New York: McGraw-Hill.

Ryan, R. M., \& Deci, E. L. (2001). On happiness and human potentials: A review of research on hedonic and eudaimonic well-being. Annual review of psychology, 52(1), 141-166.

Santrock, J.W. (2002). Life Span Development. Jakarta: Erlangga.

Seligman, M. E. (2004). Authentic happiness: Using the new positive psychology to realize your potential for lasting fulfillment. New York: Simon and Schuster.

Sugiyono. (2012). Metode Penelitian Kuantitatif Kualitatif. Bandung: Alfabeta.

Suryani, I. (2008). Perbedaan Kepuasan Perkawinan Antara Wanita Bekerja dan Wanita Tidak Bekerja. Skripsi. Depok: Fakultas Psikologi Universitas Indonesia.

Watson, D., Clark, L. A., \& Tellegen, A. (1988). Development and validation of brief measures of positive and negative affect: the PANAS scales. Journal of Personality and Social Psychology, 54(6), 1063. 